\title{
Guanine Plus Cytosine Content of the Deoxyribonucleic Acid of the Leuconostocs and Some Heterofermentative Lactobacilli
}

\author{
ELLEN I. GARVIE, VERA ZEZULA, and VALERIE A. HILL
}

\author{
National Institute for Research in Dairying, Shinfield, Reading RG2 9AT, England
}

\begin{abstract}
The mole percent guanine plus cytosine in the deoxyribonucleic acid of 12 strains (6 species) of Leuconostoc and 9 strains (4 species) of slime-forming heterofermentative lactobacilli has been determined. Calculated from meltingtemperature curves, the values were in the range 40 to $47 \%$, but calculated from buoyant-density determinations they were 2 to $4 \%$ lower. The melting temperature of the reference deoxyribonucleic acid from Escherichia coli $\mathrm{K}-12$ was 0.7 to 1 degree higher than the expected figure of $90.6 \mathrm{C}$. This point is discussed.
\end{abstract}

The mole percent guanine plus cytosine $(\% \mathrm{G}+\mathrm{C})$ in the deoxyribonucleic acid (DNA) of bacteria classified in the genus Leuconostoc is known only for a single strain of Leuconostoc mesenteroides $(6,10) . \mathrm{G}+\mathrm{C}$ data for representative strains of all the species of Leuconostoc are reported here and are compared with those of representative strains of slime-forming species of the heterofermentative lactobacilli, namely, Lactobacillus confusus, Lactobacillus viridescens, Lactobacillus vermiforme, and Lactobacillus trichodes.

\section{MATERIALS AND METHODS}

Bacterial strains. With one exception, the strains were from the National Collection of Dairy Organisms (NCDO) Reading, England, and most have been used in previous taxonomic studies $(3,11)$. The exception was a strain of $L$. trichodes (NCDO 1985) received from R. E. Kunkee, University of California, Davis. (The strains are listed in Table 2.)

Escherichia coli NCDO 1984 (=NCTC 10538; $=\mathrm{K}-12$ ) and the neotype strain of $E$. coli (NCDO 1989; =NCTC 9001), both obtained from the NCTC, were used to obtain reference DNA preparations.

Growth of cultures for isolation of DNA. The media used have been described earlier $(3,11)$. Strains of nonacidophilic leuconostocs, Lactobacillus confusus, $L$. viridescens, and $L$. vermiforme were grown in medium 1, which was supplemented with cysteine for Leuconostoc cremoris, Leuconostoc lactis NCDO 533, and $L$. vermiforme NCDO 1965. Leuconostoc oenos was grown in medium 1 adjusted to $\mathrm{pH} 4.8$ and supplemented with tomato juice and cysteine-hydrochloride.

L. trichodes was grown in a special medium (Kunkee, personal communication). It contained (wt/vol): $2.0 \%$ tryptone (Difco); $0.5 \%$ yeast extract (Difco); $0.5 \%$ peptone (Difco); $0.5 \%$ glucose; and (vol/vol): $25 \%$ Oxoid tomato juice; $0.005 \%$ Tween 80 ; $\mathrm{pH}$ 5.5. The medium was sterilized at $15 \mathrm{lb}$ for $15 \mathrm{~min}$ in 5.0-ml quantities in $0.25-\mathrm{oz}$ screw-capped bottles. Before use, $0.88 \mathrm{ml}$ of $95 \%$ ethanol was added per each $5.0 \mathrm{ml}$ of medium. When larger volumes were required, the medium was prepared and sterilized without glucose and tomato juice. The glucose was dissolved in the tomato juice; this solution was sterilized by Seitz filtration and then was added aseptically to the rest of the medium. Ethanol, in the same proportion as above, was also added before inoculation. The culture was grown at $22 \mathrm{C}$ for 7 days.

Cells were harvested, where practical, from cultures in the late logarithmic or early stationary phase of growth. For most strains this was reached in $18 \mathrm{~h}$ or under. Some strains grow slowly, and with these it is difficult to estimate the stage of growth. For these strains, cells were harvested when cell numbers were high, as judged by cloudiness in the medium. They are marked with footnote $c$ in Table 2 .

$E$. coli was grown on nutrient agar slopes and harvested after $18 \mathrm{~h}$ of incubation at $30 \mathrm{C}$.

Preparation of DNA. The method of Marmur was used (5), but the initial stages of isolation were modified to achieve suitable lysis of the cells.

After harvesting, the cells were washed once in $0.1 \mathrm{M}$ ethylenediaminetetraacetic acid (EDTA)-0.15 M $\mathrm{NaCL}$ (pH 8.0) (EDTA-saline) and then were suspended in the same solution as described in the original method. A $10-\mathrm{mg}$ amount of lysozyme was then added for each 2- to 3-g (wet weight) of cells, and the suspension was incubated at $37 \mathrm{C}$ overnight. Pronase dissolved in EDTA-saline was predigested for $1 \mathrm{~h}$ at 37 $\mathrm{C}$, and was added to the lysed cell suspension at the rate of $1.0 \mathrm{mg} / \mathrm{ml}$. Pronase was allowed to act for $1 \mathrm{~h}$ at $37 \mathrm{C}$, after which the solutions were deproteinized with phenol-water saturated with $0.15 \mathrm{M} \mathrm{NaCl}$ plus $0.015 \mathrm{M}$ trisodium citrate (SSC), pH 7.0 (7). Marmur's technique (5) was followed thereafter. L. viridescens 
was not sensitive to lysozyme in EDTA-saline, but DNA was obtained from cells lysed in 3\% 4-amino salicylate SSC (E. I. Garvie, manuscript in preparation).

Preparation of DNA for buoyant-density determinations was usually stopped after the first spooling, but in a few instances the DNA prepared for meltingtemperature $\left(T_{m}\right)$ determinations was used.

Estimation of the concentration of DNA. The concentration was calculated either from the optical density at $260 \mathrm{~nm}$ or, for greater accuracy, from determinations of deoxypentose by using the diphenylamine reagent (1).

Determination of $\mathbf{T}_{\mathbf{m}}$. DNA was carefully dispersed in SSC, and the thermal denaturation curve was determined stepwise by using a Unicam SP500 with a two-cell, electrically heated cell holder (Adkins \& Son, Leicester). The temperature of the DNA solution was measured by using a thermistor (TH-B 11 RS components) placed in the liquid but above the light path. A few $T_{m}$ measurements were made substituting a thermocouple (Copper-Ferry Wiggins Nickel Alloys) for the thermistor and measuring the resistance on a digital volt meter (Fenlow type 501).

The $\% \mathrm{G}+\mathrm{C}$ was calculated from the equation $\% \mathrm{G}+\mathrm{C}$ $=2.44\left(\mathrm{~T}_{\mathrm{m}}-69.4\right)$ (ref. 2$)$.

Determination of buoyant density $(\rho)$. The density of DNA was determined in $\mathrm{CsC} 1$ gradients formed by ultracentrifugation (9). Reference DNA from $E$. coli NCDO 1984 and DNA of unknown density were diluted in tris(hydroxymethyl)aminomethane $(0.1$ $\mathrm{M})+$ chloride buffer, $\mathrm{pH} 8.5$, to give final concentrations of 11 and $15 \mu \mathrm{g} / \mathrm{ml}$, respectively. Special grade $\mathrm{CsC} 1$ (60\% wt/wt in aqueous solution) was obtained from British Drug Houses Ltd., Poole.

To obtain the correct density for the reference DNA to migrate to about the midpoint of the density gradient, the $\mathrm{CsC1}$ solution was mixed with the DNA solution in a proportion of 13 to $1(\mathrm{wt} / \mathrm{wt})$. This gave a solution with concentrations of $0.79 \mu \mathrm{g} / \mathrm{ml}$ for $E$ coli and $1.07 \mu \mathrm{g} / \mathrm{ml}$ for the unknown DNA.

About $0.7 \mathrm{ml}$ of the solution was placed in a cell containing a $4^{\circ}$ single-sector, $12-\mathrm{mm}$, aluminum-filled Epon center piece. To avoid shearing the DNA, the cell was filled by using a pipette before the upper window holder was fitted. Samples were centrifuged at $20 \mathrm{C}$ in a Spinco model $E$ analy tical ultracentrifuge at 44,770 rpm. After $20 \mathrm{~h}$, ultraviolet absorption and schlieren photographs were taken by using, respectively, an Ilford FP 4 professional film and an Ilford G 30 chromatic backed plate. A wavelength setting of 266 $\mathrm{nm}$ was found to give best absorption patterns. The positions of the bands and peaks relative to the reference hole were measured using a modified Shadowmaster Model C.R.P. Mk 2 (Watson, Manasty \& Co.)

Densities were calculated by using the position of the standard DNA as a reference 12 . The buoyant density of the DNA at a distance $r$ from the center of rotation was obtained from the following equation: $\rho$ $=\rho_{0}+4.2 \mathrm{w}^{2}\left(\mathrm{r}^{2}-\mathrm{r}_{0}^{2}\right) \times 10^{-10} \mathrm{~g} \mathrm{~cm}^{-3}$, where $\rho_{0}=$ density of the standard DNA, $w=$ speed of rotation in radian $\sec ^{-1}, r_{0}=$ distance of the standard DNA from the center of rotation. The buoyant density of the reference $E$. coli DNA was taken to be $1.710 \mathrm{~g} \mathrm{~cm}^{-3}$.

The $\% \mathrm{G}+\mathrm{C}$ was calculated from the equation $\% \mathrm{G}+\mathrm{C}$ $=1038.47(\rho-1.6616)$ (ref. 2$)$.

\section{RESULTS}

Reference DNA. The buoyant density of the reference DNA was not determined but was taken from the literature $(2,12)$. The $T_{m}$ was measured, and the published figure for $\mathrm{K}-12$ (=NCDO 1984) is 90.6 (2). This is also the value for the $T_{m}$ of NCTC 9001 (L. R. Hill, personal communication). The figures given in Table 1 are 1 degree above these values, but values above $91 \mathrm{C}$ have previously been found for DNA from $E$ coli $(8,13)$. However, these values were not for $\mathrm{K}-12$ or the neotype strain. Neither the DNA nor the SSC in which the DNA is dissolved appeared to be at fault. Thermistors are less reliable than other meters for measuring temperature. In order to test the reliability of the $T_{m}$ values estimated by the thermistor, a few comparisons were made by using a thermocouple. The $\mathrm{T}_{\mathrm{m}}$ values obtained for $E$. coli NCDO 1989 DNA were 91.4 and 91.3 by using, respectively, the thermocouple and the thermistor; the values for $L$. viridescens NCDO 1987 DNA were 87.5 and 87.3. The cause of the high values obtained is still under investigation.

$\% \mathrm{G}+\mathrm{C}$ in lactic-acid bacteria. Mean $\mathrm{T}_{\mathbf{m}}$ and $\rho$ values for the strains examined are given in Table 2. All $T_{m}$ values were estimated at least

TABLE 1. Melting temperatures obtained for the DNA of two strains of $E$. coli

\begin{tabular}{|c|c|c|c|c|c|c|}
\hline \multirow[b]{2}{*}{$\begin{array}{c}\text { No. of } \\
\text { estimates }\end{array}$} & \multirow[b]{2}{*}{$\begin{array}{l}\text { No. of } \\
\text { DNA } \\
\text { prepn }\end{array}$} & \multicolumn{3}{|c|}{$\mathrm{T}_{\mathbf{m}}$} & \multicolumn{2}{|c|}{$\frac{\mathrm{nm} 260_{\max } \text { after heating }}{\mathrm{nm} 260 \text { room temperature }}$} \\
\hline & & Mean & $\begin{array}{l} \pm \text { Standard } \\
\text { error of } \\
\text { mean }\end{array}$ & Range & Mean & Range \\
\hline $\begin{array}{l}\text { NCDO 1984, } 8 \\
\text { NCDO } 1989,10\end{array}$ & $\begin{array}{l}5 \\
2\end{array}$ & $\begin{array}{l}91.7 \\
91.7\end{array}$ & $\begin{array}{l} \pm 0.092 \\
\pm 0.085\end{array}$ & $\begin{array}{l}91.2-92.00 \\
91.3-92.3\end{array}$ & $\begin{array}{l}0.28 \\
0.34\end{array}$ & $\begin{array}{l}0.25-0.31 \\
0.30-0.38\end{array}$ \\
\hline
\end{tabular}


TABLE 2. Melting temperature, buoyant density, and $\% G+C$ of the DNA of 21 strains of lactic acid bacteria

\begin{tabular}{|c|c|c|c|c|c|}
\hline Species & NCDO no. & $\mathrm{T}_{\mathrm{m}}(\mathrm{C})$ & $\% \mathrm{G}+\mathrm{C}^{a}$ & $\rho$ & $\% \mathrm{G}+\mathrm{C}^{b}$ \\
\hline \multirow[t]{3}{*}{ Lactobacillus confusus . . . . . . . . . } & 889 & 88.5 & 46.7 & & \\
\hline & 930 & 88.4 & 46.2 & 1.7044 & 44.5 \\
\hline & 1586 & 88.8 & 47.2 & 1.7050 & 45.0 \\
\hline \multirow[t]{4}{*}{ L. viridescens $\ldots \ldots \ldots \ldots \ldots \ldots \ldots$} & 403 & 87.4 & 44.0 & 1.7004 & 40.3 \\
\hline & 1179 & 87.3 & 43.7 & & \\
\hline & 1655 & 87.5 & 44.2 & 1.7009 & 40.8 \\
\hline & 1987 & 87.3 & 43.7 & 1.7001 & 39.9 \\
\hline L. trichodes . . . . . . . . . . . . & $1985^{c}$ & 86.5 & 41.7 & 1.7007 & 40.6 \\
\hline L. vermiforme . .............. & $1965^{c}$ & 86.8 & 42.6 & & \\
\hline \multirow{2}{*}{ Leuconostoc mesenteroides . . . . . . . . } & 523 & 86.2 & 41.0 & 1.6989 & 38.7 \\
\hline & 768 & 86.9 & 42.7 & 1.7009 & 40.8 \\
\hline \multirow[t]{2}{*}{ L. dextranicum } & 529 & 86.1 & 40.8 & & \\
\hline & 812 & 86.3 & 41.1 & 1.6976 & 37.3 \\
\hline \multirow[t]{2}{*}{ L. paramesenteroides . . . . . . . . } & 803 & 86.4 & 41.5 & & \\
\hline & 871 & 86.0 & 40.5 & 1.6993 & 39.2 \\
\hline \multirow[t]{2}{*}{ L. lactis $\ldots \ldots \ldots \ldots \ldots \ldots \ldots \ldots \ldots \ldots \ldots$} & $533^{c}$ & 88.0 & 45.3 & 1.7034 & 43.4 \\
\hline & 546 & 88.3 & 46.2 & 1.7052 & 45.3 \\
\hline \multirow{2}{*}{ L. cremoris $\ldots \ldots \ldots \ldots \ldots \ldots \ldots$} & $543^{c}$ & 86.6 & 42.0 & 1.6987 & 38.5 \\
\hline & $828^{c}$ & 87.4 & 43.8 & 1.6985 & 38.3 \\
\hline \multirow[t]{2}{*}{ L. oenos. . . . . . . . . . . . . . } & $1674^{c}$ & 86.8 & 42.3 & & \\
\hline & $1707^{c}$ & 86.4 & 41.4 & 1.6983 & 38.1 \\
\hline
\end{tabular}

${ }^{a}$ Calculated from the equation $\% \mathrm{G}+\mathrm{C}=2.44(\mathrm{~T} \mathrm{~m}-69.4)$.

${ }^{b}$ Calculated from the equation $\% \mathrm{G}+\mathrm{C}=1038.47(\rho-1.6616)$.

${ }^{c}$ Slow-growing strains requiring more than $24 \mathrm{~h}$ incubation.

twice, and for most strains more than one preparation of DNA was examined. The variation between different determinations using $E$. coli DNA is shown in Table 1. Similar variation was obtained with DNA for other species. When $\% \mathrm{G}+\mathrm{C}$ was calculated, it was found that the value calculated using $T_{m}$ was higher than the value calculated using $\rho$. With $L$. mesenteroides NCDO 768 (strain 39), the value for $\rho$ agrees with the figure of 1.701 published by Schildkraut et al. (10), whereas the $\mathrm{T}_{\mathrm{m}}$ is higher than the value of 85.5 published by Marmur and Doty (6). This discrepancy is probably linked with the high $\mathrm{T}_{\mathrm{m}}$ found for $E$. coli DNA.

The only other comparisons which can be made with published figures relate to $L$. viridescens. Two strains were examined previously (4), and both originated from the NCDO, namely NCDO 403 and 1987. One of these strains, NCDO 1987 (=S40E), was reported as having a buoyant density of 1.695 , which did not correlate with the chemical estimation of $41.0 \% \mathrm{G}+\mathrm{C}(2)$. The values for both of these strains have been redetermined and, while that for NCDO 403 is close to the value of 1.7015 given by Gasser and Mandel (4) for the same strain, that for NCDO 1987 is higher. The new figure of 1.7001 gives a $\% \mathrm{G}+\mathrm{C}$ which is in closer agreement with that calculated from $T_{m}$ and with the chemical estimation than the earlier value. It is also close to the value for other strains of the same species.

\section{DISCUSSION}

The general pattern of the results shows that the $\% \mathrm{G}+\mathrm{C}$ of strains of the genus Leuconostoc fall within narrow limits. Within this same range are included the figures for the lactobacilli examined and also for Lactobacillus brevis and Lactobacillus buchneri (4). Sharpe, Garvie, and Tilbury (11) suggested that there was a close relationship between the species examined, and the $\% \mathrm{G}+\mathrm{C}$ values obtained do not conflict with this suggestion.

Buoyant densities are normally calculated against a standard reference DNA and should, therefore, be comparable between laboratories. It is not yet customary to use a standard reference strain for $T_{m}$ measurements and to state the $T_{m}$ obtained for it. This is desirable in future published work for the results given suggest that since the $\mathrm{T}_{\mathrm{m}}$ for $E$. coli is 1 degree higher than the value published by de Ley (2), the $T_{m}$ values for the other cultures may be higher than those found in other laboratories. This difference needs to be further investigated. 


\section{ACKNOWLEDGMENTS}

We wish to thank G. C. Cheesman for assistance in the buoyant-density determinations.

\section{REPRINT REQUESTS}

Address reprint requests to: Dr. Ellen I. Garvie, National Institute for Research in Dairying, Shinfield, Reading RG2 9AT, England.

\section{LITERATURE CITED}

1. Burton, K. 1968. Determination of DNA concentration with diphenylamine, p. 163-165. In L. Grossman and K. Maldare (ed.), Methods in enzymology, vol. 12 B. Academic Press Inc., New York.

2. de Ley, J. 1969. Re-examination of the association between melting point, buoyant density and chemical base composition of deoxyribonucleic acid. J. Bacteriol. 101:738-754.

3. Garvie, E. I. 1969. Lactic dehydrogenases of strains of the Genus Leuconostoc. J. Gen. Microbiol. 58:85-94.

4. Gasser, F., and M. Mandel. 1968. Deoxyribonucleic acid base composition of the genus Lactobacillus. J. Bacteriol. 96:580-588.

5. Marmur, J. 1961. A procedure for the isolation of deoxyribonucleic acid from micro-organisms. J. Mol. Biol. 3:208-218.
6. Marmur, J., and P. Doty. 1962. Determination of the base composition of deoxyribonucleic acid from its thermal denaturation temperature. J. Mol. Biol. 5:109-118.

7. Mandel, M. 1966. Deoxyribonucleic acid base composition in the genus Pseudomonas. J. Gen. Microbiol. 43:273-292.

8. Mandel, M., and R. Rownd. 1964. Deoxyribonucleic acid base composition in the Enterobacteriaceae, an evolutionary sequence?, p. 585-597. In C. A. Leone (ed.), Taxonomic biochemistry and serology. Roland Press \& Co., New York.

9. Meselson, M., F. W. Stahl, and J. Vinograd. 1957. Equilibrium sedimentation of macromolecules in density gradients. Proc. Nat. Acad. Sci. U. S. A. 43:581-588.

10. Schildkraut, C. L., J. Marmur, and P. Doty. 1962. Determination of the base composition of deoxyribonucleic acid from its buoyant density in CsCl. J. Mol. Biol. 4:430-443.

11. Sharpe, M. E., E. I. Garvie, and R. H. Tilbury. 1972. Some slime-forming heterofermentative species of the genus Lactobacillus. Appl. Microbiol. 23:389-397.

12. Sueoka, N. 1961. Variation and heterogeneity of base composition of deoxyribonucleic acids: a compilation of old and new data. J. Mol. Biol. 3:31-40.

13. Tonomura, B., R. Malkin, and J. C. Rabinowitz. 1965. Deoxyribonucleic acid base composition and clostridial species. J. Bacteriol. 89:1438. 1439 . 